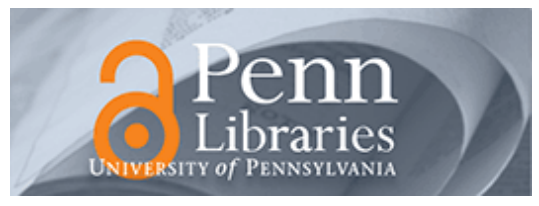

University of Pennsylvania

ScholarlyCommons

\title{
Bilingual Intercultural Education and Andean Hip Hop: Transnational Sites for Indigenous Language and Identity
}

Nancy H. Hornberger

University of Pennsylvania, nancyh@gse.upenn.edu

Karl F. Swinehart

Follow this and additional works at: https://repository.upenn.edu/gse_pubs

Part of the Anthropological Linguistics and Sociolinguistics Commons, Education Commons, and the Linguistic Anthropology Commons

\section{Recommended Citation}

Hornberger, N. H., \& Swinehart, K. F. (2012). Bilingual Intercultural Education and Andean Hip Hop: Transnational Sites for Indigenous Language and Identity. Language in Society, 41 (4), 499-525.

http://dx.doi.org/10.1017/S0047404512000486

This paper is posted at ScholarlyCommons. https://repository.upenn.edu/gse_pubs/261

For more information, please contact repository@pobox.upenn.edu. 


\title{
Bilingual Intercultural Education and Andean Hip Hop: Transnational Sites for Indigenous Language and Identity
}

\author{
Abstract \\ Exploring contemporary Aymara and Quechua speakers' engagements with multilingualism, this article \\ examines two transnational sites of Indigenous language use in Bolivia-a master's program in bilingual \\ intercultural education in Cochabamba and a hip hop collective in El Alto. Responding to the call for a \\ sociolinguistics of globalization that describes and interprets mobile linguistic resources, speakers, and \\ markets, we draw on long-term ethnographic fieldwork to explore the transnational nature of these mobile \\ and globalized sites, ideologies of Indigenous language and identity present there, and flexible language \\ practices therein. From our analysis of selected narratives and interactions observed and recorded \\ between 2004 and 2009, we argue that these sites, ideologies, and language practices constitute \\ productive spaces for Indigenous language speakers to intervene in a historically and enduringly unequal, \\ globalizing world.

\section{Keywords} \\ indigeneity, mobility, translanguaging, flexible language practices, multilingual repertoire, global hip hop \\ Disciplines \\ Anthropological Linguistics and Sociolinguistics | Education | Linguistic Anthropology
}




\title{
Bilingual intercultural education and Andean hip hop: Transnational sites for indigenous language and identity
}

\author{
N A N C Y H . H O R N B E R G E R \\ University of Pennsylvania, Graduate School of Education \\ 3700 Walnut Street, Philadelphia, PA 19104-6216, USA \\ nancyh@upenn.edu \\ K A R L F. S W I N E H A R T \\ University of Chicago, Society of Fellows \\ 5845 S. Ellis Gates-Blake 327, Chicago, IL 60637, USA \\ swinehart.karl@gmail.com
}

\section{A B S T R A C T}

Exploring contemporary Aymara and Quechua speakers' engagements with multilingualism, this article examines two transnational sites of Indigenous language use in Bolivia - a master's program in bilingual intercultural education in Cochabamba and a hip hop collective in El Alto. Responding to the call for a sociolinguistics of globalization that describes and interprets mobile linguistic resources, speakers, and markets, we draw on long-term ethnographic fieldwork to explore the transnational nature of these mobile and globalized sites, ideologies of Indigenous language and identity present there, and flexible language practices therein. From our analysis of selected narratives and interactions observed and recorded between 2004 and 2009, we argue that these sites, ideologies, and language practices constitute productive spaces for Indigenous language speakers to intervene in a historically and enduringly unequal, globalizing world. (Indigeneity, mobility, translanguaging, flexible language practices, multilingual repertoire, global hip hop)*

\section{N T R O D U C T I O N}

Exploring contemporary Aymara and Quechua speakers' engagements with multilingualism, this article examines two transnational sites of Indigenous language use, a master's program in bilingual intercultural education in Cochabamba, Bolivia and a hip hop collective in El Alto, Bolivia. ${ }^{1}$ In both of these cases, speakers' fluency in Indigenous languages and Spanish affords them added symbolic capital in the social marketplace (Bourdieu 1991) of both Bolivian and globalized, transnational networks, disrupting language ideologies of Indigeneity in the Andes. 
An account of language practices among Indigenous urban youth and professionals can illuminate the circumstance of Indigenous Andean languages in the shifting social terrain of contemporary society, often referred to by the shorthand term globalization. McKay and Bokhorst-Heng explain that one of the defining characteristics of globalization - along with internationalization, liberalization, universalization, westernization, and modernization - is deterritorialization, entailing the alteration of social space "so that space is no longer mapped in terms of territorial places, distances, or borders" (McKay \& Bokhorst-Heng 2008:2). Blommaert argues that "a sociolinguistics of globalization is perforce a sociolinguistics of mobility" and that the new theoretical challenge in sociolinguistics is to find ways to describe and interpret "MOBILE resources, MOBILE speakers, and MOBILE markets" (Blommaert 2010:28).

Whereas in the past, Andean Indigenous language and identity were always considered safe in the traditional Indigenous ayllu homelands to which young people regularly returned from long sojourns of employment away (cf. Hornberger 1988), newer generations who are spending their lives in urban, globalizing contexts are increasingly unwilling to give up the language and identity practices that define who they are, even while away from the ayllu. At the same time, transnational sites for multilingual, multimodal, and mixed-code communicative practices are increasingly available, in which Indigenous youth and professionals draw on their communicative repertoires in their entirety. These are sites entailing networks and practices in which "cultural products such as music, art, cinema and (to a lesser extent) literature appear to open new avenues to survival for languages whose fate would be otherwise pretty gloomy" (Blommaert 2010:76-77).

In the Andes, Indigenous languages like Quechua and Aymara have been recognized as "oppressed languages" (Albó 1977; Mannheim 1984) because of the articulation of social relationships of domination along ethnolinguistic lines. As languages do not exist autonomously outside of the lives of the people who speak them, Indigenous languages have largely shared common histories with Indigenous communities_-genocide and displacement. There is evidence that large scale language shift from Quechua and Aymara to Spanish is occurring among Indigenous Andean communities (Hornberger \& King 1996, 2001; Hornberger \& Coronel-Molina 2004; Howard 2007), and speakers of these languages do so more often now as bilinguals or multilinguals rather than as monolingual speakers.

The fact remains, however, that millions of Andeans today continue to speak these languages. While the socioeconomic conditions of the speakers of Quechua and Aymara are similar, and in many cases worse, than when researchers like Albó and Mannheim designated them oppressed, this designation does not uniformly or adequately describe Aymara and Quechua speakers' orientations to and use of these languages. Rather than furthering linguistic or cultural westernization, contemporary Quechua and Aymara speakers' engagements with transnational sites and networks may reinforce ethnolinguistic identity, encourage Indigenous language proficiency, and open up new domains of Indigenous language use. Whether speakers orient 
towards a global hip hop public, in which Aymara language hip hop can find a place, or towards international networks of Indigenous activists and international funders who will support aspiring indigenous professionals, in both cases we find a jump in the spatio-temporal framework for communication - what Blommaert calls a jump in scale-level (Blommaert 2010:32). Recognizing the stratified and hierarchical order of the world, these actors, even if in different fields of cultural activity, provide examples of linguistic "scale-jumping," from the local (lower scale) to the transnational (higher scale) (Blommaert 2010:35), among speakers of Indigenous languages in contemporary contexts of globalization.

Here we visit two such transnational sites in Bolivia: the PROEIB-Andes master's program in bilingual intercultural education in Cochabamba and the hip hop collective Wayna Rap of El Alto. We will take up in turn the transnational nature of these mobile and globalized sites, ideologies of Indigenous language and identity present there, and flexible language practices therein. Within each of the following sections, we draw from ethnographic fieldwork carried out between 2004 to 2009, and provide fieldnote or discourse excerpts from recorded interviews, observed and recorded interactions, and cultural products from the sites. We use our Quechua and Aymara speaking participants' real names with their permission and encouragement: Nery Mamani, Román Mamani Rodríguez (Pacha), and David Condori from PROEIB, and Wayna Rap's Grover Cañaviri, Rolando Quispe, and Juan "Eber" Quisbert. We argue that these sites, ideologies, and language practices constitute productive spaces for Indigenous language speakers to intervene in a historically and enduringly unequal, globalizing world.

\section{T R A N S N A T I O N A L S I T E S : I N D I G E N E I T Y U N T E T H E R D FROM THE L A N D?}

Both PROEIB-Andes at the University of San Simón in Cochabamba and the hip hop collective Wayna Rap of El Alto are transnational sites by virtue of their members' international links, points of reference, and communicative networks. What we find notable in both is the degree to which members engage closely with Indigeneity in their language and identity choices, even while they live largely in urban, globalized and mobile contexts far from their traditional Indigenous homes and communities.

\section{PROEIB-Andes as a transnational site}

PROEIB-Andes (Program for Professional Development in Bilingual Intercultural Education for the Andean Region, also simply referred to as PROEIB) was founded in 1996 as a six-nation consortium effort with the goal of fulfilling professional development, research, knowledge management, and cooperative network-building functions in bilingual intercultural education across the Andean countries and Latin America more generally (López 2001, 2005, 2006; Sichra 2001; 
PROEIB-Andes 2006). The program's transnationalism is evident in the international consulting and mobilizing activities PROEIB undertakes, including short courses for Indigenous community leaders; international seminars and congresses; various publication series; development of an extensive library and documentation center; and collaborative projects and consultancies with national ministries of education, academic institutions in Latin America and Europe, and international organizations such as UNESCO and UNICEF.

At its core is a thriving master's program in bilingual intercultural education, the Maestría, established at the University of San Simón in Bolivia in 1997 and enrolling Indigenous educators from Bolivia, Ecuador, Peru, Colombia, Chile, and Argentina through a selection process involving their respective ministries of education, sponsoring universities, and Indigenous organizations. Now in its seventh cycle, the Maestría has to date prepared more than 150 Indigenous educational leaders, most of them actively dispersed in multilingual educational endeavors throughout the Andean region.

Key to the success of the PROEIB Maestría is the transnational nature of the program, with participation of educators representing a broad spectrum of both national and Indigenous identities. Among the forty-one enrolled in the fourth cohort-Nery's, Pacha's, and David's cohort - there were at least ten Indigenous ethnicities and language varieties represented, including speakers of Quechua from Bolivia, Ecuador, and Peru; Aymara from Bolivia and Peru; Asheninka, Awajún, and Huampí from Peru; Mapuche from Chile; Cofán and Wayuú from Colombia; Shwar from Ecuador; and an Argentinian Colla from Jujuy. The students at PROEIB have been the beneficiaries of significant financial support from international agencies, principally the German government's Gesellschaft für Technische Zusammenarbeit (GTZ, Association for Technical Cooperation) during the first ten years of the Maestría; the presence of international aid opened doors for Indigenous students to this transnational site.

Admissions criteria require that the applicant be a speaker of an Indigenous language who self-identifies as Indigenous and is endorsed by an Indigenous community or organization. The requirement that the students be speakers of an Indigenous language undoubtedly raises the status of Indigenous languages in very concrete ways. Where earlier coming from a rural, Indigenous background had effectively been a barrier in these students' academic careers, in the competition for a place within the PROEIB masters program, it became an advantage, a prerequisite even.

The curriculum of the Maestría is transnational, with cycles of coursework in Cochabamba and fieldwork at sites across the Andean region. PROEIB students pursue an intense academic curriculum in four areas: language, culture, education, and Indigenous language. Each of their five twenty-one-week semesters of coursework also entails a significant four to eight week field component, culminating in extended ethnographic research for their master's theses in Indigenous communities and schools dispersed across all six national territories. 
Many of the students in the Maestría are transnational in the usual sense of being immigrants who maintain links and ties with their country of origin while they study and reside in Cochabamba. Additionally, all of the students traverse borders from local Indigenous nationality to nation-state while maintaining close ties and links back to their local Indigenous community, and simultaneously co-construct with their peers a transnational network and alliance of Indigenous mobilization in the Andes, Latin America, and worldwide (cf. Hodgson 2002).

The students' encounter with each other as being at once members of a shared category of Indigenous and simultaneously hailing from diverse nations, regions, political formations, and ethnicities provokes reflection on the very category of indigeneity, and in particular its loosening ties to land and language in an increasingly mobile world. Nery Mamani, a Peruvian Quechua speaker from Callalli and Cusco, alludes to this in an interview with Hornberger, reflecting on the ongoing dialogue around Indigenous identity she and her peers engaged in during the course of their graduate studies at PROEIB:

Is the Indigenous person one who lives in the countryside or in the high plain and who has no access to anything? Is that an Indigenous person? That was our question. And some were saying-whoever feels it in their heart is also Indigenous. ... And I commented to my classmates that maybe I learned to be Indigenous, or became conscious of being Indigenous, thanks to a person who is in fact not Indigenous. Yes, and that person fought for Indigenous people, for equality, for justice, and everything. That's so. She was a person involved in education. So, I said-well, I don't know. Only then did I realize that in fact, what is this? because until I became a professional, I wasn't consciously an Indigenous person. $^{2}$ (Nery Mamani, 20 June 2005)

Nery's comments index — and simultaneously challenge — a strong ideological link between the land and Indigenous identity and point instead to her professional milieu as a site of Indigenous identity formation - and moreover, through the influence of one who was not herself Indigenous.

In Nery's lifetime and experiences, as in that of her peers at PROEIB, traditional ties to the land and to herding animals on the land are loosening for Aymara and Quechua speakers in urban, globalized, mobile, and transnational contexts, and this has implications for their identities and their language practices. Nery and her peers, including Pacha and David whom we introduce below, have in their own lifetimes traversed from shepherding in remote rural Andean highlands to become westernized (occidentalizado in David's terms) educational professionals supported by and engaged in transnational sites and networks of international development and Indigenous mobilization. As we see below, these new identities are reflected in - and constructed by - the flexible language practices they engage in. 


\section{Wayna Rap as a transnational site}

The second transnational site we examine is a hip hop collective-Wayna Rap - in the city of El Alto. While the members of this collective are also Indigenous-children of Aymara migrants to the city of El Alto - they operate within different social circuits than the more upwardly mobile graduate students of PROEIB. Like them, however, their proficiency in Indigenous languages garners them greater symbolic capital within the linguistic marketplaces in which they operate.

Bolivian hip hop is a recent phenomenon emerging following the introduction of pirated US rap music in the late 90s. Its first breakthrough may have been the local success of what many recognize as the first Bolivian MC, Marcelo Yáñez-"El Cholo"-in the early 2000s (Ávila, Cárdenas Plaza, \& Prieto 2007). Since then, a dynamic hip hop scene has developed in the city of El Alto, the mainly Aymara working class bedroom community of La Paz. The majority of the MCs in this music scene rap in Spanish. Wayna Rap is a notable exception, rapping principally in Aymara, with many of their rhymes mixing Aymara, Spanish, and also Quechua.

Wayna Rap formed in 2003 out of a series of workshops convened over the radio of a youth cultural center, Wayna Tambo, only months before a major upheaval in El Alto (and Bolivia more broadly) against the government of Gonzalo Sánchez de Lozada, known as the Gas War. ${ }^{3}$ Some founding members of Wayna Rap have abandoned performance altogether in order to pursue other careers, while others have gone on to pursue other projects. Three core members of Wayna RapGrover Cañaviri, Rolando Quispe, and Eber Quisbert - still perform as Wayna Rap. Some of the other groups to emerge from Wayna Rap include Raza Insana, Diztinto, Nación Rap, Ataque de Cordillera, and Ukhamaw y Ke. Abraham Bojórquez, who performed as Ukhamaw y Ke 'That's how it is and what?,' is perhaps the artist from this scene to have gained the largest profile. In a tragic blow to Bolivian hip hop, Bojórquez died following a bus accident in early 2009.

Bojórquez's artistic name and the name of the collective Wayna Rap from which he came both echo the bilingual language practice typical of these youth. Ukhamaw $y$ Ke mixes in one utterance Aymara and Spanish: Aymara ukhamaw 'that's how it is' and Spanish y qué? 'and what?' are written with an orthography reminiscent of both innovative spelling in SMS or chat and also contemporary norms for writing /k/ in Aymara with 'k.' Wayna Rap draws on the Quechua and Aymara word for 'youth' or 'young' - wayna - and rap. Their name also references the cultural center and radio station where these MCs came together, Wayna Tambo. Although not foregrounded by the members, many of the MCs in this collective also hail from the Wayna Potosí neighborhood of El Alto, consistent with the importance many MCs worldwide place on neighborhood roots.

The remaining members of Wayna Rap continue to perform at hip hop events in El Alto, La Paz, elsewhere in Bolivia, and even abroad, and regularly make appearances on local radio and television. They have recorded a public service announcement against pollution that airs on the state run television Canal 7. Also broadcast 
on television were their two songs, Amukhim 'Silence' and Chamakat Sartasiri 'Leaving the Darkness,' and their performance at a demonstration of over one million people during a 2007 general strike in La Paz opposing the proposed transfer of Bolivia's capital to the city of Sucre.

Wayna Rap is well known not only in Bolivia but internationally as well. They traveled to Venezuela twice, in 2005 and 2007, to participate in global hip hop conferences and met US performers like Mos Def and Mortal Technique. When they traveled to Buenos Aires to perform for Bolivian audiences there, they were excited to find that Argentine rappers like Actitud María Marta were already familiar with their music through their presence on online sites like Myspace. Digital mediasharing platforms like Myspace have increased their mobility, both by bringing Aymara hip hop to new audiences and also by garnering them invitations to perform abroad.

\section{IN D I GENOUS LA NGUAGEA N D IDENT ITY}

In both sites language choice is tied to ideologies around raising the status of Indigenous languages and reversing the denigration of Indigenous identities in a heterogeneous and multilingual society. We explore these ideologies and choices for Indigenous fortification through the personal narratives and reflections of PROEIB educators and members of Wayna Rap.

\section{Indigenous language and identity at PROEIB}

Román Mamani Rodríguez, an Aymara speaker from Oruro, Bolivia, found his way to PROEIB from a position within bilingual intercultural education as a teacher and teacher trainer. His career in EIB spans the better part of its existence in Bolivia, since he was involved in the experimental programs in the early 1990s, went through the Normal School system while continuing to teach in and around Oruro with both Quechua and Aymara students, and finally went on to study for his masters at PROEIB. Currently he teaches at the Normal School in Caracollo that serves both Quechua and Aymara students studying to be schoolteachers.

As a young child, Román was teased by his classmates and called awatiri 'sheep herder' as an insult. His parents had encouraged him to speak Spanish instead of Aymara, but because of what he refers to as situaciones de la vida 'life situations,' his grandparents came to be his primary caregivers, an experience that, in his words, deepened his knowledge and love of the Aymara language. As a teenager, he crossed the border into Chile to work as an undocumented laborer north of Iquique in the region of Isluga. There he encountered Chileans who spoke Aymara differently than his grandparents. "For example," he told Swinehart, "we say jiwaña for 'to kill,' they say jaychjaña" (Román Mamani Rodríguez, 26 August 2008). Through this encounter he became aware not only of the linguistic 
diversity among Aymara speakers but also of the transnational character of the Aymara.

After returning to Bolivia and working briefly as a tailor in Cochabamba, he enrolled to study at the teacher's college in Oruro. There he decided to speak only in Aymara with his colleagues. His often repeated motto from this time was, Taqi chuyma aymar qhichwa parlt'asiñani 'With all our heart we'll speak Aymara and Quechua.' For this he was berated and called names by many of his classmates. “The Quechuas called me Nawpa Tiempo 'olden days.' They called me Defensor del Poncho 'defender of the poncho" - a word play on Defensor del Pueblo 'defender of the people,' the political office of ombudsman. For wearing his hair long, he was deemed "antipedagogical" by faculty and when it came time for his assignment to a school, the administration, in what they believed to be a punishment, assigned him to a Quechua speaking community. Instead, he viewed this as an opportunity and learned Quechua through visiting students' families in evenings and working in the fields with them.

Transforming an intended humiliation into an opportunity is also evident in his response to the names used by others to ridicule him. To his students and colleagues, he is not Román Mamani Rodríguez but Pacha, the shortened version of the name he uses in his professional life-PachaWaranqa WiñayTupu KusiKusi. From the time his primary classmates called him awatiri to being called names by his fellow teachers in training at the Normal school, naming became a central point of contention in his personal battle with his Indigenous identity. He describes this process as becoming "pickled" from all of the insults - estoy bien curtido ya - and instead of ignoring the insults, his strategy has been to embrace the name calling, changing his name altogether into a heuristic for his philosophy about life and teaching - in this world (pacha) we are thousands (waranqa) always (wiñay) and by every measure (tupu) happy, proud and not oppressed (kusi kusi).

Pacha has developed what he calls the Kusi Kusi Strategy for education, in which his goal is to involve his students in an educational process that is creative, dynamic, participatory, and above all happy (kusi kusi). He entices his students with an education that embraces both universal and local knowledges and, incredibly, employs magnetically attractive teaching materials that cost less than ten cents and use neither pen nor paper. When his pupils tell him he's crazy, he replies: "Tranquilo, con ponchógrafo, con el awayu desde allí. Con la lectura, con mi teoría, mi experiencia de allá. Ponchógrafo, awayógrafo, chalinógrafo, mantillógrafo!" 'Take it easy, [we can do it] with ponchography, with an awayu from there [referring to Andean tradition]. With reading, with theory, with my experience from over there [referring to PROEIB]. Ponchography, weavography, shawlography, textilography!'

Pacha's commitment to bilingual intercultural education moves beyond improving the existing educational practices to fundamentally changing them by introducing local semiotic systems that do not rely on pen and paper, for example, Andean textiles like awayus and ponchos. Pacha's introduction into the classroom of local 
knowledge that has previously been outside the realm of the school resonates with Nery's analogous approach to using Quechua in every day life.

Nery similarly advocates strongly for-and practices - use of the Indigenous language - in her case Quechua - and Indigenous cultural practices, in public, urban spaces.

If we don't use the language, making phone calls, writing on the internet, getting in a taxi, on the bus, to speak there, going to the market speaking Quechua, to a supermarket and speak Quechua, if we don't do it, who will? (Nery, 20 June 2005)

Nery grew up proud of her family and of her family name, Mamani, yet without a conscious sense of Indigeneity. She and her sisters spent their school vacations with their grandparents in her hometown in Callalli, herding sheep and alpacas. They dressed in the colorful hand-embroidered clothing typical of the region, which they would also automatically change out of when they left Callalli to return to their studies in Sicuani. Later in the same interview, she continues on the theme of Indigenous identity in relation to language:

What are Indigenous features? It's skin color, it's an Inca nose like this. And it has a lot to do with language. Whoever speaks Quechua is from the country. Even though today it's changing a little because many people in the city are learning Quechua for employment needs. Now there are many Quechua academies in Cusco. And moreover they don't find work if they only speak Spanish. (Nery, 20 June 2005)

Her comment indexes the ideological link between Indigenous identity and Indigenous language. Acknowledging that language is a powerful marker of identity, she also highlights the changing times and urban venues that imbue the Indigenous language with added symbolic capital.

Nery's master's thesis research is on revitalizing Indigenous languages, which are for her one of the most conspicuous elements of Indigenous identity and intimately related to other Indigenous resources, including natural resources, peoples, communities, practices, and agricultural production. She is concerned over the loss of Indigenous languages and of the knowledges carried in them.

There's another thing that's been catching my attention ... oral traditions and dialogue within the Indigenous group. When they did their interviews with me, one of the ... the little grandma, no? She began to talk, talk, talk ... she described with so much sweetness, tenderness, I don't know. It's like that, no? So if the grandmother dies, with her dies all that she knows and now with the influence of the media of communication, with the highway that's arrived to the last community, all that used to be practiced and lived is getting lost, the traditional practices of Indigenous peoples are getting lost. And I think that inside all those 
practices there's a lesson. There's a cultural wealth, no? I believe that there's a unique respect but nevertheless, that now is being lost. (Nery, 20 June 2005)

As a professional bilingual intercultural educator and researcher, Nery identifies paradoxical ideologies in Indigenous communities as to the role of the schools in revitalizing Indigenous languages. On the basis of her fieldwork in a bilingual school on the urban periphery of Cusco - the urban-rural frontier as she calls it — she found that:

In my fieldwork, ... speaking with teachers, with parents, I think there is a necessity of giving attention to the language.... they say it's a shame that Quechua is getting lost ... but nevertheless sometimes the teacher doesn't teach in Quechua. ... Parents say that now for example our children don't want to speak Quechua but moreover it embarrasses them, those who don't speak it are embarrassed. But we see that in order to work let's say being professionals, if they are to be professionals, if they are to work in the rural area, they need Quechua to communicate. So, there's a contradiction, no? The school [doesn't] want to use the language but nevertheless the parents say that in the future when they're professionals, the children could need the language ... One parent said ... for our children not to be ashamed to speak Quechua, it would be good if it could be promoted. Imagine that! He says Quechua should be promoted. (both laugh) And Quechua is theirs! And that's what he says, he says it should be disseminated through the media, radios, television, that the authorities should provide standards [normas]. But I tell him that there is a standard, the Languages Law. In Peru the Ministry of Education has a whole bilingual intercultural administration but nevertheless, that's not known. They aren't aware. In the communities, the parents, the users of the language, the owners I'd say, don't know that these norms exist, in favor of their language. (Nery, 20 June 2005)

On the one hand, schoolteachers lament the loss of Quechua, yet don't teach it, and on the other, parents relate that their children don't want to speak Quechua but at the same time are ashamed not to, and furthermore, that they will need it for their future employment. Parents paradoxically look to the schools and wider society to spread the language, though they themselves are the ones who speak it. The owners of the language, as Nery puts it, look to the state to defend their language, and yet are unaware of official measures already in place.

David Condori, Bolivian Quechua speaker from Potosí and Nery and Pacha's colleague at PROEIB, has experienced both the westernizing threat to his language and identity through schooling, and the revitalizing value of returning to Quechua through the literacy he originally learned in Spanish. A Quechua speaker born in a rural highland community of Potosí, he suffered greatly throughout his monolingual Spanish schooling, and especially in learning to read and write, but eventually completed a Normal School teaching degree and served as a rural classroom teacher for twelve years before joining up to Bolivia's National Education Reform of 1994, 
with its implementation of bilingual intercultural education. He underwent a twoweek training course in Sucre and went on to become a pedagogical advisor in the Reform. It is through the Reform, and especially with his own students, that he has learned to read and write in Quechua: "junto con mis niños he aprendido" 'I learned alongside my students.' He has been so successful with Quechua literacy that he became a regional technical expert, participating in the Quechua text production project and teaching Quechua and Spanish as a second language pedagogy at Potosí's Normal School.

For David, literacy in Quechua is not just about revitalizing the language, but also revitalizing identity- “no la revitalización de la lengua, tal vez la revitalización de la identidad" 'not language revitalization, perhaps the revitalization of identity.' He registers a difference between being Quechua or just a Quechua speaker.

School was westernizing me, then after I took that professional development course in 1993, it made me reflect and I assumed my identity, no? From that point, that reflection, that professional development experience, from that time, I returned to recognizing myself as Indigenous ... Now for sure, I can tell you that, "I'm Quechua" not "I'm a Quechua speaker" as many others, no? It's something very different. I'm Quechua. So, that was, let's say, the wake-up call [el tirón de orejas] that the course in Totoko was for me. (David Condori, 18 February 2005)

David hopes to write down the Quechua stories his grandparents used to tell him when he was a child, since he believes it is through those stories that a people communicates their feelings, their teachings, and their identity. He proceeds to narrate one of his grandparents' stories in Quechua in the context of his interview with Hornberger, the only of her PROEIB maestría interviewees to provide extended discourse in Quechua in the midst of an interview in Spanish.

\section{Indigenous language and identity at Wayna Rap}

David's concern for his grandparents' stories or Nery's recognition of the eloquence of the elderly women in her fieldwork might leave an impression that the production of Indigenous verbal art is largely restricted to older generations. Yet, we examine here the cultural production of a group of Aymara youth who dedicate themselves to refining their verbal skills through the composition of verses principally in Aymara, but also in Quechua and Spanish. Like David, Pacha, and Nery, members of Wayna Rap view their work as an intervention in response to affronts to Indigenous language and culture and a sense that the Indigenous language is being spoken less. Simultaneously, however, Wayna Rap's language choice defies the presumption that once in the city, bilingual Aymara youth rush to abandon their heritage language for Spanish (cf. Guayaga 2000) and flows from their perceptions of the dynamics of multilingualism in their society, specifically 
concerning Aymara's low status. They spoke to this in an interview with Swinehart in 2007.

(1)

Karl: What's been the reception of youth, of adults, of older people, of Aymara speakers?

Rolando: The reception has been good, right?

Grover: At first, regarding the youth it was bad. They discriminated against you. They said, 'Ah! those llamas, those llamas are singing in Aymara. They're some Indians, some T'aras [anti-Indian slur].To sing in Aymara is absurd. But we thought it's the best.

Calling their peers "llamas" for speaking Aymara is a painful example of selfloathing, of appropriating an existing racist discourse in Bolivia that dehumanizes Indians by referring to them as animals - the ones most emblematic, even, of the surrounding countryside, creatures that have no place in city. In his reanimation of his detractors' voices, Grover poetically aligns llama with indio and the epithet t'ara - an anti-Indian racial slur. It is not strange that many of the children of Indigenous migrants to cities like El Alto would identify with an African-American cultural expression like hip hop given the shared social conditions of racism, discrimination, and poverty faced by both groups. This name-calling is also reminiscent of the experience faced by Pacha when he insisted on speaking Aymara within the context of the teachers' college. Like Pacha, however, these MCs show determination to reverse the denigration of their Indigenous culture and language.

Grover: But we thought it's best [to sing in Aymara] because partly in those towns where the custom of speaking Aymara is getting lost, earlier in the countryside they spoke purely in Aymara but now it's between Aymara and Spanish like that.

Rolo: In the schools too they teach in Spanish and not in Aymara any more.

Grover: And it's getting lost, so we thought, we said, let's rap in Aymara because we believe that it's ours and because also you're going to help another generation.

Rodolfo: One idea is that they feel proud, that they not be embarrassed to speak in Aymara. When they arrive from the countryside, people obligatorily have to learn Spanish and from there they forget their dialect [sic].

Rolo: It's a big shock. Someone that is an Aymara speaker and arrives here to La Paz and everything is in Spanish. It's hard to learn and later it's embarrassing to speak [Aymara] and later when he goes back to his own town he only speaks in Spanish.

Karl: $\quad$ To show off a little too I imagine.

Rolo: $\quad$ Yes of course. We want to divert that a little in order for people to acquire those habits of speaking in Aymara. What better way than hip hop, let's say that it's a central point? And we don't make comercial hip hop but rather with the message we try to [persuade others to] value our culture more, our grandparents, good things.

Grover: During adolescence more than anything because everyone looks at you-that one's Aymara. Here there's a little bit of discrimination even among ourselves. We live where one person has their house, and the other person doesn't have anything and so, yes. And if the other speaks Aymara everyone puts him down, with his arrival from the countryside, and he can't even speak Spanish well. Little by little, I was taking nourishment, and I said this has to be done, hip hop in Aymara, because hip hop is 
attitude, it's strength, it's youth energy and I think that when someone is listening, he's going to put on that attitude and that pride, and I don't say in order to fight, but of being oneself, we're continuing to develop ourselves and the times are changing and if we lose our languages, our ancient customs, then I think that we're going to encounter a level where, damn it, and now? What do we do then?

Rolo: lost

Grover: What do we do then? Lost. So, I wouldn't want that to happen, to my children, possibly to my grandchildren and that wave [of the future].

Here, Grover and Rolo frame their language choice both in terms of intergenerational language shift and the cultural denigration propelling it. By performing in Aymara they intervene by example, using Aymara in a sphere that had been dominated first by English and later, as Latin American hip hop developed, by Spanish. The symbolic importance of Aymara in hip hop differs markedly from the Bolivian higher-education context where Spanish is supported by preexisting ideologies of language prestige. In contrast, hip hop internationally tends to challenge what Alastair Pennycook calls the "ortholinguistic practices" of standard language ideologies (Pennycook 2007). Wayna Rap's use of Aymara is both a countervalorization to racist discourses denigrating everything Indigenous and also consistent with the emphasis hip hop cultures across the globe place on "keepin' it real," being true to one's community, self, and roots (Morgan 2005). This ethos of keeping it real, when introduced into a context of global hip hop, means that MCs respond in locally specific contexts to notions of authenticity, or realness. For Bolivian MCs, in a majority Indigenous country, with a strong Indigenous political consciousness particularly among the Aymara, Indigeneity and realness are intimately connected. For example, the spaces of Bolivian hip hop regularly invoke Indigeneity through their names-Wayna Tambo 'youth meeting/resting place' (in both Quechua and Aymara), Centro Taypi 'Center center' (in Spanish and Aymara, respectively), to name two venues in La Paz. In March of 2006, when there was what was perhaps Bolivia's largest national hip hop festival in the city of El Alto, the festival's name was Aymara-Qhana Aru Imantata 'the Hidden, Clear Voice.' 'Hidden' refers in one sense to "underground" hip hop, but can also help us reflect on the intelligibility of Wayna Rap's Aymara rhymes when heard by non-Aymara audiences. When Wayna Rap performs in Aymara it is often for audiences who may have only some, if any, Aymara speakers. Similar to the emblematic use of Indigenous languages in the place names just mentioned, Aymara language lyrics remain intelligible for non-Aymara speaking fans in Bolivia and internationally, if not as a denotational/grammatical code, as an emblem of Indigenous realness and authenticity.

MULTILINGUAL REPERTOIRES AND FLEXIBLE

LANGUAGE PRACTICES AS SPACES FOR

INDIGENOUS LANGUAGE PROFICIENCY AND USE

We turn now to consider Indigenous language proficiency and use more closely, as enacted in these speakers' multilingual repertoires and flexible language practices. 
Like Blommaert (2010) following Hymes (1996), we are interested in multilingualism not as a "collection of 'languages' that a speaker controls, but rather as a complex of specific semiotic resources ... people actually possess and deploy" (Blommaert 2010:102) — bits and pieces of languages, registers, "varieties and modalities, styles and genres, ways of using language as a resource" (Hymes 1996:70). With Blommaert, we recognize that some of the bits and pieces of these speakers' Indigenous language proficiency are truncated, in the sense that fluency in one genre or social domain doesn't necessarily imply fluency in another (Blommaert \& Backus 2011:19), but also that communicative repertoires are often largely built up of such partial, truncated competences, "specialized to differing degrees, and above all dynamic, all of this following the idea that language knowledge is built up in usage-based fashion" (Blommaert \& Backus 2011:23). Yet, for those very reasons, and because truncation implies a reduction of something previously more expansive, we prefer to characterize multilingual repertoires and flexible language practices deployed in these two transnational sites as affording evolving (rather than truncated) Indigenous language proficiency and use.

\section{Multilingual repertoires and flexible language practices at PROEIB}

Following are three scenes, taken from our observation fieldnotes and recorded interviews at PROEIB, illustrating the multilingual repertoires and flexible language practices at play in PROEIB and the ways in which these open up spaces for developing Indigenous language proficiency and use. We use the notion of flexible language practices here in the sense in which it has recently been theorized and documented in educational contexts by Blackledge \& Creese (2010) in their ethnographic studies of complementary schools - community-based schools serving heritage language learners in Britain:

Flexible bilingualism captures the 'heteroglossic' nature of communication in the bilingual context of complementary schools. It leads us away from a focus on 'languages' as distinct codes to a focus on the agency of individuals in a school community engaged in using, creating, and interpreting signs to communicate to multilingual audiences. (Blackledge \& Creese 2010:109)

These and other authors argue that recognizing and incorporating flexible language practices in multilingual classrooms put the emphasis on speaker voice and agency rather than on 'language' and code-switching, and offer the possibility for teachers and learners to access academic content through linguistic resources they bring to the classroom while simultaneously acquiring new ones (Cummins 1979 on interdependence; Hornberger 1989, 2003 on continua of biliteracy; Gutiérrez, Baquedano-López, \& Tejeda 1999 on hybridity; Baker 2003 and García 2007, 2009 on translanguaging; Saxena 2010 on bilingual supportive scaffolding practices). 


\section{Analyzing a bilingual Quechua-Spanish interview transcript} in an ethnography workshop

The Maestría faculty practice and promote an ethnographic, social constructivist, and interpretive research orientation. During a workshop on ethnographic research methods with the fourth PROEIB cohort, Hornberger asked the students to collaboratively analyze a two-page excerpt from an interview carried out in a fluid mixture of Quechua and Spanish. What ensued was a highly variable performance across four working groups and across individuals within those groups, drawing on their evolving multilingual repertoires in flexible ways to accomplish the task.

One group moved systematically through the steps of segmenting the transcript, choosing a segment to analyze, and applying tools of discourse analysis, relying greatly on one student's very clear notes on Hornberger's lecture in Spanish and another's fluent proficiency in reading and translating between Quechua and Spanish. Two other groups bogged down in the task of literally reading and translating the transcript, since none of their members had sufficient proficiency in Quechua; they did however persist and made headway. The last group, though not as effective as the first in mobilizing their linguistic resources to analyze the code-switching discourse of the interview, nevertheless had some excellent interpretive insights. They inferred that the interviewee might have been in a bilingual education program, since he makes passing reference in the interview to his writing in Quechua - an inference that was perhaps a reflection of their own experience of acquiring Quechua reading and writing (after learning Spanish reading and writing in school) through involvement in bilingual education (Cochabamba, Bolivia, 11 September 2004).

The workshop interaction exemplifies some of the ways the Maestría students' classroom practices regularly enabled them to draw from across their multiple languages and literacies in accomplishing academic tasks collaboratively: across the groups, individuals pooled their evolving linguistic repertoires, academic skills, and experiential insights to read, translate, analyze, and interpret the transcript. Three PROEIB Maestría participants have written about strategies of interdialectal communication in Quechua within PROEIB (Luykx, Julca G., \& García R. 2005). In the next scene, three Maestría students collaborate across their evolving multilingual repertoires and Aymara language proficiencies to complete a different genre of academic task.

\section{Preparing a poster for class presentation}

In a more recent PROEIB Maestría cohort, Swinehart observed and videotaped an activity in which three Bolivian Aymara speakers worked together to prepare a poster in Aymara for their upcoming class presentation. The three students-Bartolina, Tupak, and Julián (all pseudonyms) - differ greatly in their Aymara proficiency. Bartolina and Tupak are fully bilingual Aymara speakers who speak Aymara at home and with peers. Julián, by contrast, grew up with a father who 
refused to speak Aymara to him and punished him if he spoke it. Although his mother spoke Aymara with him, he does not communicate in the language with facility. Both Bartolina and Tupak have occupied professional positions where they have been able to use Aymara in the workplace as rural bilingual teachers, whereas Julián has not had similar professional experience. In contrast to both Julián and Bartolina, Tupak has formally studied Aymara linguistics at the university level (see Figure 1).

In the activity, the three students composed a short text in Aymara for a class presentation. Bartolina and Tupak, the authors of the text, discussed content, composed sentences, and deliberated word choice. They then dictated to Julián and monitored his writing on a large piece of paper destined for presentation to the class. These two subactivities together allowed them to achieve the stated goal of the activity, creating a presentation illuminating a selection of assigned text. In addition to "making a presentation," however, there was another goal for this activity. The students aimed to have a presentation that would demonstrate to their classmates and professors their mastery of course content as well as fluency

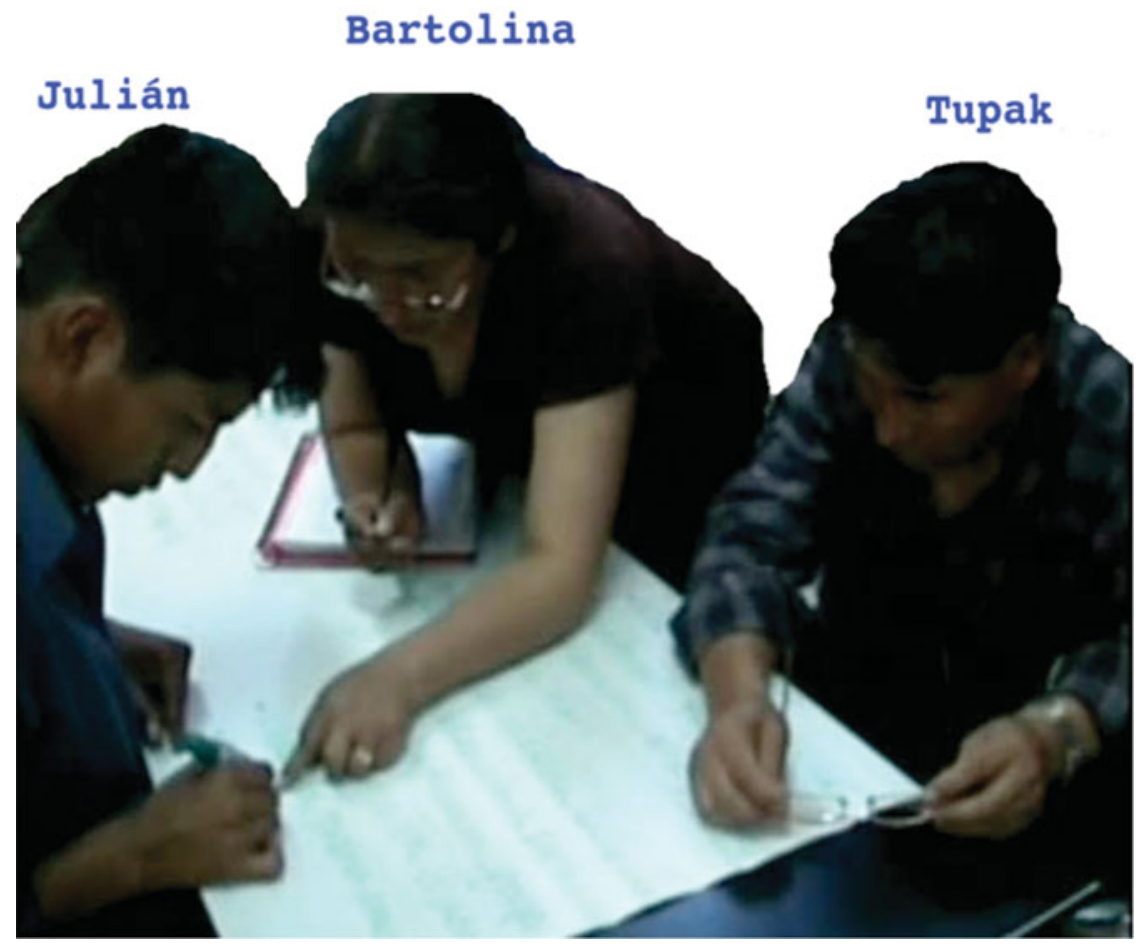

FIGURE 1. Composing poster text in Aymara for a class presentation. 
and eloquence in Aymara. One third of the class speaks Aymara and both of the professors understand Aymara.

Julián aimed to improve his spoken and written Aymara, and both Bartolina and Tupak were supportive of this. In a larger sense, all of them are enrolled in this program partly because of its focus on using Indigenous languages within a higher education context. The use of a language in a new domain brings with it demands to explain new concepts and realities.

This became relevant in the course of writing their text. Bartolina and Tupak took on the task of articulating in Aymara concepts they have read in Spanish, such as "reading constructs meaning." Below, "reconstructs" is abandoned for "constructs," drawing on the term for house construction, here used metaphorically. Bartolina provides a candidate translation in line 19; Tupak provides an embodied enactment of "thinking about it," running his hands through his hair and sitting down (18), coordinated with a question $(20,22)$, and followed by a ratification in line 24 and a nod of his head (see Figure 2). ${ }^{4}$

\section{(3) Aymara; Spanish}
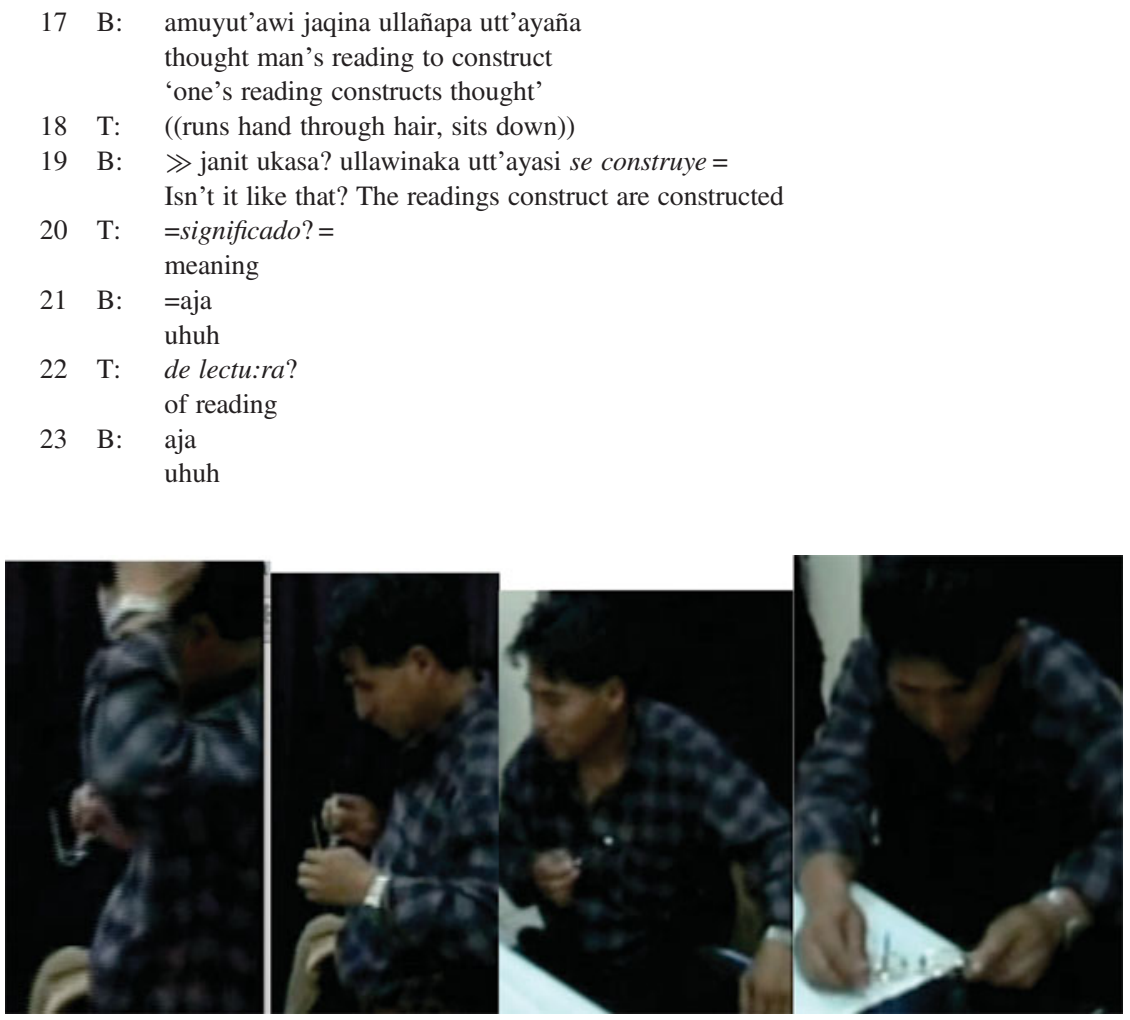

FIGURE 2. Word search and deliberation embodied. 
24 T: utt'ayasi se construye

construct are constructed

((nods head)) [See Figure 3]

In this metalinguistic exchange the dynamic between Bartolina and Tupak constitutes him as the expert in relation to Bartolina, while Bartolina provides the object of evaluation for Tupak's assessment, that is, the translation of concepts read and discussed in Spanish into Aymara. In the course of this deliberation, Julián is excluded from commenting on the content of the text and the conceptual work of translation is left to Bartolina and Tupak. Whether or not Bartolina and Tupak think he could contribute in such a discussion, they do not engage him as a legitimate conversation partner for this part of the task. Julián's role is to write the text that Bartolina and Tupak develop.

Upon viewing the video recording of this interaction, Julián acknowledged his marginalization within the production of the text, but this did not mean necessarily that he was ill at ease with the arrangement. He remarked that Bartolina's patient and persistent interventions with his Aymara writing had taught him a great deal. This expert/novice interaction for language learning was not the initial design of student groups. The course instructors had grouped the students according to language group, but without attending to the heterogeneity of language skills. This particular group of students, however, recognized strengths and weaknesses among themselves and established a hierarchy concerning expertise in Aymara literacy. Having noted the positive dynamic in this particular Aymara language group,

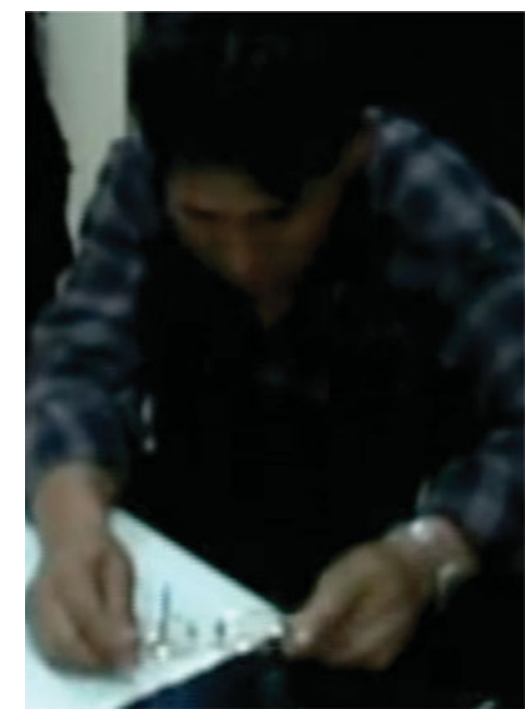

FIGURE 3. Deliberation is closed with a nod of the head. 
the course instructors later explicitly encouraged students to collaborate in such a way as to increase interaction between more fluent and less fluent speakers, and to consciously attend to less fluent students' language skills.

The above exchanges between Tupak and Bartolina, and Julián's exclusion from them, serve as a prelude to later interactions where Julián's participation was largely limited to orthography. Throughout the rest of the activity, a hierarchy of participant roles emerged through and about language use. Bartolina gave directives to Julián and evaluated his writing. Tupak assessed both Julián's writing as well as Bartolina's translations. Tupak was also afforded time to talk with members of a neighboring group, coming in just to "check in" as the "final word" while Bartolina completed the heavy lifting of working with Julián (see Swinehart 2008a for a fuller discussion). Within this activity we find multiple orders of indexicality (Silverstein 2003; Blommaert 2005:69) with students orienting to one another in a "game of roles," achieving status as Aymara experts. They vie for this position within their work group, within their cohort of students in the larger class; and as participants in the Masters degree program they make an intervention in Bolivian society upturning the larger "linguistic marketplace," in Bourdieu's (1991) sense, by valuing Aymara expertise as a prestige achievement of professional distinction.

\section{Translating, summarizing, and presenting a reading assignment}

Pacha describes his time at PROEIB as an experience that was both classically academic and rigorous, demanding more reading than had ever previously been expected of him, and a time of encounter with other Indigenous people from across the Andes that also vindicated his insistence on using Aymara within spaces like the university. Where earlier in his life he had experienced ridicule for his conviction to speak Aymara within the higher-education context, at PROEIB he encountered an entirely different response.

Facing the challenge of reading a short text in English and providing a summary for class discussion, Pacha struggled through the process of translating as he read, but still felt most able to articulate what he had read in Aymara. He decided to warn the instructor that he had prepared his presentation in Aymara instead of in Spanish. He recounts the experience:

I read it all, this word with the dictionary, with the little translator, there, I managed to get it out in Spanish. As it's a diploma in bilingual intercultural planning, I thought I'm going to summarize this in Aymara, in my language, every bit of it. I understood my report in Aymara-Excuse me Dr. Inge. I read in English. I tried to understand and summarize in Spanish, [but] I've done my report in Aymara. Please excuse me. - Good! - and the professor congratulated me. Later I thought, it's possible, I thought, to qualify as a translator. Once I'd 
been congratulated, this encouraged me. That's a challenge. (Pacha, 26 August 2008)

The challenge of reading a text in the foreign language was combined with the challenge of articulating an academic discussion in his native Aymara. Securing space within an academic setting for the use of this Indigenous language had been a challenge previously in Pacha's life, but here became cause for celebration and approval from the course's instructor, Dra. Inge Sichra.

\section{Multilingual repertoires and flexible language practices at Wayna Rap}

We cannot speculate on what Pacha's assessment of the music of Wayna Rap would be, but we know that he uses music regularly in his own teaching as part of his estrategia kusi kusi 'kusi kusi strategy' and that lengua con ajayu 'language with soul' is central to his philosophy. Ajayu is a Quechua/Aymara concept for the spirit or soul (Orta 1999). Wayna Rap, as most practitioners of verbal art, aim to deliver lengua con ajayu through their performances. In this section, we discuss Wayna Rap's lyrics and describe a workshop run by the collective with youth from El Alto.

Wayna Rap performs in an idiom legible internationally as hip hop while incorporating local elements of Aymara culture. They sample bass drums and wind instruments typical of Andean music and regularly perform in ponchos and wear the knit hats typical of Aymara men. For those without access to Aymara as a linguistic code, the language may be just another emblem of Indigeneity like ponchos and wind instruments, but for those who understand the lyrical content of their songs, there are powerful references to Aymara history.

In any Aymara cultural institution - educational, religious, sindical-somewhere there will be a portrait of Tupak Katari, a leader and martyr of a 1781 panAndean revolt against Spanish colonialism. Though the institution of Bolivian hip hop has no walls for portraits, Wayna Rap's rhymes keep Tupak Katari's voice sonicly present through the reentextualization of his now famous last words: "Nayasaparukiw jiwayapxista, waranqa waranqanakaw kutt'anipxani." 'You only kill me, but I will return and I will be millions.'

One of their most widely circulated songs on the internet, Chamak'at Sartasiry, now also available on a Sony Records compilation of global hip hop, intertextually draws on these famous last words (in Aymara):

(4) waranqa waranqa waranqanakawa waranqa waranqa waranqanakawa Aymar markaxa wilampi Tupaj Katari 'there are millions, millions' 'there are millions, millions' 'the Aymara nation with the blood of Tupak Katari'

Coming together during the Gas War of 2003, Wayna Rap reentextualize Tupak Katari's last words not only within the genre of hip hop but also within a frame of 
contemporary insurrection. Eber Quisbert, the MC who composed the first rap in Aymara, Ch'ama, told Swinehart that these events moved him to "rap his reality":

(5) Eber: In 2003 it started a little bit for me. Goni [former Bolivian President González Sánchez] left and all that. I hit the street, checked out everything that was happening, I saw how people had died and that reality I began to tell, to rap that reality.

This commitment to express their life in verse provides one way of understanding palabra con vida 'word with life' and lengua con ajayu. Wayna Rap members have been conducting workshops since 2004, and a glimpse into one of them enables us to see that Eber's commitment to rap his reality is not a solo endeavor, but a larger aim of this collective. In 2007, Swinehart visited two of these workshops, which were held in the heart of El Alto at the Alcaldía Quemada 'burned city hall.' Swinehart writes:

The alcaldía is a phoenix of sorts in that it was burned during the 2003 insurrection, and has since been reclaimed and renovated as a cultural center that is constantly buzzing with activity - the municipal symphonic orchestra rehearses, dance troupes practice folkloric routines for parades, black-clad heavy metal bands rehearse, and Wayna Rap holds its workshops. Waiting outside the building for Grover, who had invited me to the workshop, I am standing near a long line of people waiting to enter to watch Ballet Illimani and young dancers outside sell tickets for 10 bolivianos (not quite two dollars). Grover arrives with his partner, Ivana, a Spanish teacher at an El Alto high school; she greets me in Aymara-Kamisaki jilata? waliki? 'How are you brother? good?' I respond in Aymara, but that is as far as our Aymara interaction extends before she continues in Spanish to explain her excitement that some of her students may come to the workshop.

When the workshop begins, the participants include four women and five men, all in their late teens and early twenties. Grover gives an opening talk about hip hop, mentioning its beginnings in the Bronx as part of African American culture and as belonging to a moment of protest. He states that now there is hip hop all over the world, and Wayna Rap and this workshop are about making a Bolivian contribution. By rapping in Aymara, he explains, Wayna Rap stay true to their roots (lo hacen más originario 'they make it more Indigenous') and secure that the language does not disappear.

He then asks that they suggest topics for composing a song together. A young woman in a pink hooded sweatshirt makes her contribution, "a disease is infecting our country and one cure could be what we're doing. Hip hop could cure the country." They continue to have an open, political discussion assessing the state of life in Bolivia, touching on many issues - the character of a recent referendum, the racism faced by Andean migrants to the east of the country, their own hopes for Bolivian hip hop's future. 
After forty minutes of conversation, Grover encourages them to reflect on the conversation and to take time to individually compose rhymes. Some take out pen and paper, others elaborate their first drafts in lowered voices in the room's corners. After sufficiently rehearsing their verse, they convene a cypher. Three of the women, including the school teacher, have composed a chorus (in Spanish) to transition between each participant's verse.

(6) Pobreza, pobreza Bolivia no progresa y a los padres de la patria no les interesa.

Progresa, progresa Bolivia No a la pobreza!

\author{
'Poverty, poverty \\ Bolivia doesn't progress \\ and the country's leaders \\ don't care \\ Progress, progress Bolivia \\ No to poverty'
}

Some of the intervening verses are only a few lines, others are longer; many address the lack of unity in the country, and a full range of political positions are expressed, from explicit support for Evo Morales to more skeptical denunciations of politicians, from calls for dialogue to calls for open class warfare. With the exception of an occasional Jallalla - the Quechua and Aymara Que Viva - all of the rhymes are in Spanish, even Grover's; but Indigeneity still features prominently within their rhymes. The young MC in the pink hooded sweatshirt articulates one of the most politically radical of the verses specifically in terms of Indigenous identity (21 August 2008).

(7) Por sólo unos cuantos acabados nos quieren ver pero lo que no saben es que mi wiphala llevo en mi ser la defenderé a cualquier lado con ella yo iré con ella respeto yo me ganaré Unamosnos Aymaras Quechuas Hagamos fuerza Y a la burguesía saquemosles lo que tienen de la cabeza Y tengan cuidado Que me toca la siguiente pieza Raperos llegamos con fortaleza

\author{
'Just some finished-off ones \\ they want to see us \\ but what they don't know \\ is that my wiphala I carry in my being \\ I will defend her, anywhere \\ with her I'll go \\ with her I'll win respect \\ Aymaras and Quechuas let's unite \\ make strength \\ and take from the bourgeoisie \\ what they have from their heads \\ and be careful \\ it's my turn next \\ We rappers are coming strong'
}

She references the Indigenous flag, the Wiphala (Quechua/Aymara 'flag'), the rainbow checkered flag of the Collasuyu from Inca times now emblematic of Indigenous social movements. It may seem odd that the semantic contrast to Quechua/ Aymara is not another ethnic category but one of social class - "bourgeois." This is common in Bolivia where class and ethnic identities have often served as proxies for each other even when things are often more complicated. Aymara women, for 
example, are famous for their business acumen and quite a few urban Aymara are, in fact, wealthy merchants.

Not all of Wayna Rap's rhymes are as politically explicit as the example from the workshop above. For example, the first piece of Aymara hip hop, Ch'ama, mentioned above, is denotationally quite vague. Despite its lack of referential specificity, it effectively develops a sense of urgency in the face of confrontation and establishes a sense of unity between the MC and his audience (Swinehart 2008b).

(8)

Puriñani mä uru
lak'aru
puriñani mä uru
saxranaka jutt'apxi
jan axsaramti
wali ch'amampi nuwasiñani
atipañani
khuchi saxranakaru jiwayañani
ch'ama
akankaskiwa
akankaskiwa

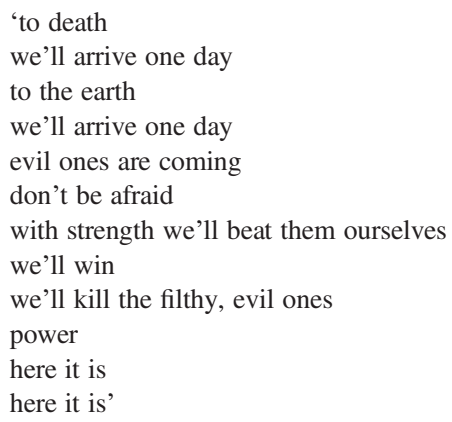

On the recorded track this short verse repeats multiple times as the song advances, adding layers of Eber's voice over the initial loop producing an effect between a round and complete cacophony. Bauman \& Briggs have said that "performance provides a frame that invites critical reflection on communicative processes. A given performance is tied to a number of speech events that precede and succeed it" (Bauman \& Briggs 1990:60-61). Considering this, we might understand the track's recording as modeling its own future repetition and providing instructions on "how to use it." In other words, the internal organization of the track provides a model of repetition and many voices, becoming a chorus of voices united in ch'ama, multiplying into hundreds, thousands, millions of voices. As a short verse that can be learned and repeated, we can imagine this taking place in a workshop like the one described above, or informally among a group of friends, or as a refrain to oneself during a daily commute.

While the lyrics of Ch'ama are completely Aymara, the lyrics of Chamakat Sartasiri mix Quechua and Aymara. This is thanks to Eber, a student of linguistics at the Universidad Mayor de San Andrés, who has learned Quechua as an additional language through classroom instruction there. His fellow MCs told me that he is determined to compose more rhymes in other Indigenous languages and has expressed interest in also learning Guaraní, the third most widely spoken Indigenous language of Bolivia. In both their determined multilingualism and their commitment to authenticity and Indigeneity, Wayna Rap opens up new uses and proficiencies in Indigenous languages, in a transnational, globalized, and mobile world. 
Although embedded within different cultural and political projects, both the MCs of Wayna Rap and the professional graduates from PROEIB make interventions regarding language choice in spaces where Indigenous languages have previously been absent or regarded as abject. Both groups' interventions are motivated by perceptions of accelerating language shift as symptomatic of cultural loss. Simultaneously, however, the category Indigenous is recognized by international funders, in the case of PROEIB, and international audiences, in the case of Wayna Rap, through fluency in an Indigenous language, affording the speakers in question access to resources and prestige. The value placed on language skill is not only placed externally through scholarships to PROEIB, or invitations to hip hop congresses, but also achieved interactionally in face-to-face interaction as speakers of these languages assess each others' status as language experts and identities as Indigenous people. The engagement of both the masters students of PROEIB and the MCs of Wayna Rap with cosmopolitan networks is predicated on their pertaining to Indigenous communities. The foray into global networks is at once a departure from narrow territoriality and highly dependent on the Indigenous languages' indexicality of particular local identities. The multilingual repertoires on which these Quechua and Aymara speakers draw represent par excellence "the mobility of concrete semiotic resources ... in a globalized context" (Blommaert 2010:47).

Blommaert asserts that "existing inequalities in the world system extend from material to symbolic domains when people become mobile in globalization processes" and it is unreasonable to "make any a priori assumptions about the repertoires of people in globalization contexts" (Blommaert 2008:439). The mobility he refers to concerns African migrants in Europe interfacing with state authorities, a scenario very different from the cases we discuss here. Nevertheless, we can see how the international flow of resources and information impact the life trajectories and linguistic repertoires of the Indigenous Andeans we have discussed here. The existing inequalities in Andean societies that motivate international agencies like GTZ to fund a program like PROEIB extend into the symbolic domain of linguistic competence in Indigenous languages as a marker of group membership in the category of person the agency aims to support. The inequality in material resources available to the youth of El Alto vis à vis their more wealthy counterparts in the south of La Paz becomes inversely proportional to their symbolic wealth within the transnational, largely online, sphere of global hip hop. Their use of Aymara and Quechua together with the deployment of other signs of Indigenous belonging (clothing, sampled Andean music, wiphalas), within a broader idiom of hip hop, establish them as authentic and performatively "keep it real."

Through establishing hip hop and higher education as fields where Indigenous language expertise is not only heard but rewarded, the linguistic market is shifted in favor of multilingualism rather than conceding to Spanish language hegemony. 
The multilingual repertoires, flexible language practices, ideologies of Indigeneity, and transnational sites we have described here constitute productive spaces for Indigenous language speakers to intervene in a historically and enduringly unequal, globalizing world.

A P P E N D I X: T R A N S C R I P T I O N C O N VENT I O N S

$\begin{array}{ll}(()) & \text { transcriber comments } \\ \text { equal sign }(=) & \text { continuous talk } \\ ? & \text { rising intonation } \\ >> & \text { rapid speech } \\ : & \text { lo:ng vowel }\end{array}$

N O T E S

*We gratefully acknowledge Luis Enrique López and PROEIB-Andes faculty, staff, and students for hosting Nancy as participant observer, particularly during the IV Maestría 2004-2006 course trajectory, and equally for hosting Karl during 2007. We especially thank Nery Mamani, David Condori, Román Mamani Rodríguez (Pacha), and the three anonymous students for sharing their experiences and insights so generously with us. Karl would like to thank the members of Wayna Rap and their workshop participants for their enthusiasm for and patience with his research. Karl also thanks the Fulbright Institute for International Education, Penn's Center for Native American Studies, and the Fulbright-Hays Dissertation Research Abroad Fellowship that all supported his work in Bolivia, as well as Dr. Pamela Calla and the Universidad de la Cordillera, and Prof. Juan de Dios Yapita and the Institute of Aymara Language and Culture (ILCA) for their crucial support during his time in La Paz and El Alto. We benefited from Kathryn Howard's comments on early drafts of this work, and from lively discussion and debate at two conference sessions where we presented it - " "Bilingualism' and the new linguistic economy" at the International Symposium on Bilingualism 7, organized organized by Adrian Blackledge and Angela Creese, and "Globalization from the bottom up: Indigenous language planning and policy in globalizing spaces and places," organized by Nancy Hornberger and Teresa McCarty, at the 2011 meeting of the American Association of Applied Linguistics. We are grateful to editor Barbara Johnstone and two anonymous reviewers for incisive guidance as we finalized the article for publication.

${ }^{1}$ We capitalize Indigenous and Indigeneity when they refer to people(s), in keeping with the practice of Indigenous organizations such as the American Indigenous Language Development Institute at the University of Arizona.

${ }^{2}$ Here and throughout, interview excerpts are authors' translations from the original Spanish.

${ }^{3}$ For more on these events and a history of Bolivian social movements, see Hylton \& Thompson 2007.

${ }^{4}$ See the appendix for transcription conventions.

\section{R E F E R E N C E S}

Albó, Javier (1977). El futuro de los idiomas oprimidos en Los Andes. Lima: Centro de Investigación de Linguistica Aplicada.

Ávila, Jiovanny Samanaud; Cleverth Cárdenas Plaza; \& Patricia Prieto (2007). Jóvenes y política en El Alto. La Paz: PIEB.

Baker, Colin (2003). Biliteracy and transliteracy in Wales: Language planning and the Welsh National Curriculum. In Nancy H. Hornberger (ed.), Continua of biliteracy: An ecological framework for 


\section{NANCY H. HORNBERGER AND KARL F. SWINEHART}

educational policy, research, and practice in multilingual settings, 71-90. Clevedon: Multilingual Matters.

Bauman, Richard, \& Charles Briggs (1990). Poetics and performance as critical perspectives on language and social life. Annual Review of Anthropology 19:55-88.

Blackledge, Adrian, \& Angela Creese (2010). Multilingualism. London: Continuum.

Blommaert, Jan (2005). Discourse: A critical introduction. Cambridge: Cambridge University Press. (2008). Bernstein and poetics revisited: Voice, globalization and education. Discourse and Society 19:425-51.

(2010). The sociolinguistics of globalization. New York: Cambridge.

— \& Ad Backus (2011). Repertoires revisited: 'Knowing language' in superdiversity. Working Papers in Urban Language and Literacies 67:1-26.

Bourdieu, Pierre (1991). Language and symbolic power. Cambridge, MA: Harvard University Press.

Cummins, Jim (1979). Linguistic interdependence and the educational development of bilingual children. Educational Research 49(2):222-51.

García, Ofelia (2007). Foreword. In Sinfree Makoni \& Alastair Pennycook (eds.), Disinventing and reconstituting languages, $\mathrm{xi}-\mathrm{xv}$. Clevedon: Multilingual Matters.

(2009). Bilingual education in the 21 st century: A global perspective. Malden, MA: WileyBlackwell.

Guayaga, Germán (2000). Ser joven en El Alto: Rupturas y continuidades en la tradición cultural. La Paz: PIEB.

Gutiérrez, Kris D.; Patricia Baquedano-López; \& Carlos Tejeda (1999). Rethinking diversity: Hybridity and hybrid language practices in the third space. Mind, Culture, and Activity: An International Journal 6(4):286-303.

Hodgson, Dorothy (2002). Indigenous rights movements. American Anthropologist 104:1037-97.

Hornberger, Nancy H. (1988). Bilingual education and language maintenance: A southern Peruvian Quechua case. Berlin: Mouton.

- (1989). Continua of biliteracy. Review of Educational Research, 59(3): 271-96.

(ed.) (2003). Continua of biliteracy: An ecological framework for educational policy, research and practice in multilingual settings. Clevedon: Multilingual Matters.

— \& Serafin M. Coronel-Molina (2004). Quechua language shift, maintenance and revitalization in the Andes: The case for language planning. International Journal of the Sociology of Language 167:9-67.

— \& Kendall A. King (1996). Language revitalisation in the Andes: Can the schools reverse language shift? Journal of Multilingual and Multicultural Development 17:427-41.

- (2001). Reversing Quechua language shift in South America. In Joshua A. Fishman (ed.), Can threatened languages be saved? 'Reversing language shift' revisited: A 21st century perspective, 166-94. Clevedon: Multilingual Matters.

Howard, Rosalyn (2007). Por los linderos de la lengua: Ideologías lingüísticas en los Andes. Lima: Instituto de Estudios Peruanos.

Hylton, Forrest, \& Sinclair Thompson (2007). Revolutionary horizons: Past and present in Bolivian politics. London: Verso.

Hymes, Dell H. (1996). Ethnography, linguistics, narrative inequality: Toward an understanding of voice. Bristol, PA: Taylor and Francis.

López, Luis Enrique (2001). Literacies and intercultural bilingual education in the Andes. In David R. Olson \& Nancy Torrance (eds.), Literacy and social development: The making of literate societies, 201-24. Malden, MA: Blackwell.

_ (2005). De resquicios a boquerones: La educación intercultural bilingüe en Bolivia [From fissures to craters: Bilingual intercultural education in Bolivia]. La Paz: PROEIB Andes y Plural Editores.

(2006). Cultural diversity, multilingualism and indigenous education in Latin America. In

Ofelia García, Tove Skutnabb-Kangas, \& María Torres-Guzmán (eds.), Imagining multilingual schools: Languages in education and glocalization, 238-61. Clevedon: Multilingual Matters. 


\section{BILINGUAL INTERCULTURAL EDUCATION AND ANDEAN HIP HOP}

Luykx, Aurolyn; Félix Julca G.; \& Fernando García R. (2005). Estrategias de comunicación interdialectal en Quechua. Proceedings of the conference on Indigenous languages of Latin America-II/Memorias del congreso de idiomas Indígenas de Latinoamérica-II, organized by the Center for Indigenous Languages of Latin America (CILLA), Teresa Lozano Long Institute of Latin American Studies at the University of Texas at Austin, University of Texas at Austin.

Mannheim, Bruce (1984). 'Una nación acorralada': Southern Peruvian Quechua language planning and politics in historical perspective. Language in Society 13:291-309.

McKay, Sandra Lee, \& Wendy D. Bokhorst-Heng (2008). International English in its sociolinguistic contexts: Towards a socially sensitive ESL pedagogy. New York: Routledge.

Morgan, Marcyliena (2005). After...word! The philosophy of the hip-hop battle. In Derrick Darby \& Tommie Shelby (eds.), Hip hop and philosophy: Rhyme 2 reason, 205-322. Chicago: Open Court.

Orta, Andrew (1999). Catechizing culture: Missionaries, Aymara, and the 'new evangelization.' New York: Columbia University Press.

Pennycook, Alastair (2007). Language, localization, and the real: Hip-Hop and the global spread of authenticity. Journal of Language, Identity, and Education 6:101-15.

PROEIB-Andes (2006). Interculturalidad y bilingüismo en la educación superior: Desafíos a diez años del PROEIB Andes. Cochabamba, Bolivia: PROEIB Andes.

Saxena, M. (2010). Reconceptualising teachers' directive and supportive scaffolding in bilingual classrooms within the neo-Vygotskyan approach. Journal of Applied Linguistics \& Professional Practice 7(2).

Sichra, Inge (2001). Huellas de intraculturalidad en un ámbito intercultural de educación superior. In Maria Heise (ed.), Interculturalidad: Creación de un concepto y desarrollo de una actitud, 193-202. Lima, Peru, Programa Marco de Formación Profesional Tecnológica y Pedagógica en el Perú (FORTE-PE).

Silverstein, Michael (2003). Indexical order and the dialectics of sociolinguistic life. Language \& Communication 23:193-229.

Swinehart, Karl F. (2008a). Achieving expertise in an Indigenous heritage language class. Philadelphia: University of Pennsylvania, Ms.

(2008b). Tupac in their veins: Wayna rap and the semiotics of urban Indigeneity. Paper presented at the 2008 annual meeting of the American Anthropological Association.

(Received 27 January 2011; revision received 28 October 2011; accepted 22 November 2011; final revision received 10 January 2012) 